\title{
Correlations between Executive Pay, Equity Incentive and Corporate Performance: Empirical Analysis Based on Panel Data of China's Listed Companies
}

\author{
Huiguan Ding \\ College of Economics \& Management, Nanjing Institute of Industry Technology \\ PO box 210046, No.1 Yangshan North Road, Nanjing, China \\ Tel: 86-25-8586-4221Ｅ-mail: dinghg1972@163.com \\ Jiansheng Cai \\ Shandong Zhaojin Investment Co., Ltd. \\ PO box 265400, No.5 Jintai Luofeng Road North, Zhaoyuan, China \\ Tel: 86-535-824-2270Ｅ-mail: gaoyuan3881@126.com \\ Yanxia Niu \\ Department of Finance, Jiangsu Academy of Safety Science \& Technology \\ PO box 210042, No.9 Huayuan Road, Nanjing, China \\ Tel: 86-25-8547-7640Ｅ-mail: Niuyx1977@163.com
}

Received: April 18, 2012

Accepted: May 10, 2012 Published: July 15, 2012

doi:10.5430/ijfr.v3n3p24

URL: http://dx.doi.org/10.5430/ijfr.v3n3p24

\begin{abstract}
The global recession triggered by the subprime mortgage crisis in 2009 has aroused reflections over executive pay system. Domestic and foreign theorists have not yet reached a unanimous conclusion in their research on relationship between executive compensation incentives and corporate performance, especially correlations between executive pay and executive shareholding ratio and equity concentration degree. There also exist large differences in the empirical results. This paper, on the basis of reviewing the previous research results, takes component stocks of Shanghai 180 and Shenzhen 100 indices during 2007-2009 as samples and tests the correlations between executive pay, equity incentive and corporate performance of China's listed companies through multiple regression analysis, which is of great significance to direct the practices in executive compensation system reform of China.
\end{abstract}

Keywords: Executive pay, Equity incentive, Corporate performance, Correlation

\section{Introduction}

Since the reform and opening up 30 years ago, China's overall economic system has realized transition from planned economy to market economy gradually, and the corporate governance mechanism has developed accordingly from administrative management, via the period of double means governance, to modern enterprise system in 1993. The most important feature of modern enterprises is separation of enterprise ownership from management right and the consequent appearance of principal-agent relationship. The purpose of agency is to employ the "agents" who are more capable in running business to manage the enterprise to realize maximization of the benefits of the "principals". The direct questions brought about by agency are those of the so-called agency cost and inspiration, In order to reduce agency cost, a kind of contract or mechanism should be designed from the standpoint of the principals to provide the agents certain incentives and restraints and to make the agents' decisions tend to be in favor of maximization of the principals' utility. In 1998, it is the first time for China's listed companies to disclose annual salaries and shareholdings of the senior management teams in their annual reports. From then on, executive pay of listed companies keeps on being a hot social concern and sensitive topic. On the whole, the overall level of top management compensation keeps 
improving steadily year by year, and great progress has also been made on incentive and restraint mechanism for managers. However, the reform in this aspect is lagged behind obviously, and the backward level of executive compensation system construction has become a main bottleneck, which restricts the promotion of enterprise management level in China and has a serious impact on management efficiency and sustainable development of the enterprises. Therefore, it is an urgent matter to establish an efficient executive compensation incentive system in the reform of enterprise system of China.

In 2009, a global recession triggered by the subprime mortgage crisis has profound impact on the world economy, and most companies are suffered from falling sales, blocked loans and downturn share prices. In the reflections of the crisis, it is considered that the peculiar "radical, high-risk, high-yield" salary system of Wall Street is the seed of the bad situations, and that the lack of risk control and government regulation still accelerates the outbreak of the crisis. To review and redesign the compensation mechanism is deemed to be an important measure to improve and strengthen corporate governance and government regulation. On February 5, 2009, President Obama issued a "pay restriction order"; and the European Union commission began to encourage its member states to use for reference the order on February 6 . At present, more and more enterprises adopt a conservative salary strategy and orient the basic salary to the market mean. On one hand, it is the result of the rushing pressure of short-term cash after the crisis. However, the more important reason is that the market and shareholders intervene more and more in the constituting of salary policies and the disclosure of pay data. They emphasize that "salary incentives must be based on corporate performance". Moreover, large companies tend to adopt long-term incentive tools such as equity incentive in a higher proportion, and reduce the use of short-term cash incentive correspondingly. Furthermore, governments of all counties have strengthened the supervision of executive pay. The governments of the United States, Britain, Switzerland, France, Germany and China have begun to implement gradually executive compensation control and enhance the requirements of disclosure of executive pay.

On the basis of previous research achievements, this paper takes component stocks of Shanghai 180 and Shenzhen 100 indices during 2007-2009 as samples, and makes a concrete investigation on the empirical relations between executive pay, equity incentive and corporate performance of China's listed companies, which is of great significance to direct the practices in executive compensation system reform of China.

\section{Literature Review}

\subsection{Foreign Research Achievements}

Modern researches on executive compensation originate mainly from the agency theory, which requires that executive pay be designed to make the interests of the shareholders be consistent with that of the managers so as to minimize agency costs. Among them, the earliest study on interest conflicts between managers and shareholders is finished by Jensen and Meckling (1976). They define "agency cost" and ascertain the various institutional arrangements to reduce all these costs, including equity ownership, capital structure, debt contract and compensation incentive. All these work has laid theoretical foundation for the research on correlation between executive pay and corporate performance.

Murphy (1985) takes 73 manufacturers in the United States during 1964-1981 as samples, conducts a research on the relationship between executive compensation structure and stock returns based on the payment data of 500 management personnel from the sample companies, and finds that there exist positive correlations between total compensation changes and stock returns and between cash compensation and stock returns. Coughlan and Schmindt (1985) sample relevant data of 149 companies in 1978-1982, investigate the relationship between the changes of executive cash compensation and enterprise performance, and discover that there exists positive correlation between salary changes and stock price performance.

Daniel and Thomas (2003) test the relationship between executive pay and surplus management, and find that surplus management is more likely to be adopted when there is a close relationship between the potential executive compensation and the returns of stocks or options they hold in a company. The specific manifestation is that: when the company's earnings grow very well, the executives exercise their rights by a large margin and get profits, and then the earnings slump.

Lucian and Yaniy (2005) control variables related to company income in the past such as return on equity, earnings per share growth and sales growth, test the relationship between CEO compensation and firm size, and find that they have positive correlation. Furthermore, they discover that the executive pay level of the top $25 \%$ large companies is $25 \%$ higher than that of the $25 \%$ smaller companies, and that executive pays increase gradually when the companies expand their firm scales.

From the above, we can see that western scholars achieve agreements by and large on the relationship between executive 
pay, equity incentives and corporate performance, though partial researchers draw different conclusions.

\subsection{Domestic Research Achievements}

Compared to the west, domestic scholars start studying on the relationships between executive pay, equity incentives and corporate performance quite late. In 1998, China's listed companies begin to disclose related information on annual salaries and shareholdings of their executives. From then on, researches on correlations between executive pay; equity incentives and corporate performance of listed companies gradually arouse the interest of the academic circles, and gradually become one of the hottest topics of domestic theoretical circles, businesses and social public opinions. Overall, there are biggish differences in the results of the study on the problem of the Chinese scholars.

Li Zengquan (2000) conducts a research based on information of executive pay and shareholding disclosed by China's listed companies in 1998, and finds that there has no correlation between annual executive compensation and corporate performance, and that executive pay is closely related with firm size with a remarkable regional difference. Wei Gang (2000) samples 816 listed companies in 1999 which disclose annual executive salaries, and the research indicates that there is no significant positive correlations between annual executive pay and executive shareholding or corporate performance, and that there is a significant positive correlation between executive pay and firm size, and that there does not exist an "interval effect" between executive shareholdings and corporate performance. Lin Xiaowan (2001) makes longitudinal comparison over CEO compensation and shareholding status of China's listed companies during 1998-2000, and discovers that executive compensations take on a trend of growth, but shareholding ratio of operators is on the low side, and that the conditions are not mature for stock options to play an incentive role.

Chen Zhiguang (2002) makes a study on executive pay taking listed companies in Shanghai market as samples, and finds that executive pay is in significant positive correlation with corporate performance, the scale of the enterprise, proportion of legal person share etc. Hu Ming (2003) analyses information of annual salary, shareholding ratio of the executives and the like disclosed in the 2002 annual reports of China's listed companies, and finds that there does not exist positive correlation between annual executive pay, executive shareholding ratio and corporate performance of listed companies of China. Yan Lirong and Liu Fang (2006) carry on research over relevant data of listed companies during 2001-2004 and analyze the executive compensation incentive mechanism, and find that shareholding of the proprietors and firm size have no significant influence on executive pay.

Bai Xue (2009) conducts a research on the relationships between corporate governance, corporate performance and executive compensation of listed companies based on data during 2005-2007. The results show that the size of the board of directors, the proportion of state-owned shares, firm size and corporate performance have the most significant impact on executive compensation, and that the size of the board of directors, firm size and corporate performance are in positive relationship with executive pay, and that the proportion of state-owned shares and concentration of ownership are in negative relationship with executive compensation, and that corporate performance and executive compensation can affect each other obviously.

Zhang Jinlin and Zhao Qing (2010) collect relevant data of 597 listed companies of Shanghai Security Exchange during 2005-2007, whose research concludes that executive pay is positively related to corporate performance, firm size and $\mathrm{CEO}$ shareholding ratio and that it has a strong correlation with area and industrial variables.

\section{Empirical Research Scheme}

\subsection{Theory Assumptions}

According to above research achievements, we can first make a hypothesis to the relationship between executive pay, equity incentives and corporate performance so as to construct an interrelated mathematical model, carry on an empirical test through data of the Chinese market and analyze correlations between executive pay, equity incentives and corporate performance of China's listed companies.

(1) For the correlation between corporate performance and related factors, assume that corporate performance is positively related to annual executive pay and executive shareholding ratio. According to principal-agent theory, when there is information asymmetry between top management team and the shareholders of a company, shareholders shall sign a compensation-performance contract with the executives to reduce agency costs resulted from adverse selection and moral hazard, and thus realize the maximization of their self-interests. Under the contract, the annual executive pay will be closely connected with corporate performance. Therefore, the executives, who are also with the same pursuit of self-interest maximization, will seek to improve the operating performance so as to maximize their own annual compensation. On the other hand, there is a positive correlation between equity earnings and stock prices, while share prices are usually affected by various factors jointly and cannot be under entire control by the executives. If the executives have got some residual claims through equity incentive, they would act to maintain a high consistency with 
the interests of the shareholders, and attach importance to long-term development of the company so as to maximize their own income level. Nevertheless, when the agents have no residual claims, they would usually avoid high-risk projects and act with short-term behaviors seriously.

(2) For the correlation between executive compensation and the related factors, assume that executive pay is in positive relation with assets scale of the company, and that it is negatively related to executive shareholding ratio and equity concentration degree. Generally, the greater the scale of an enterprise is, the more the controllable resources the senior executives can manage, and the higher the abilities they are required to have. They need to deal with heavier work, look for more investment projects and manage more enterprise personnel. At the same time, they need higher management skills, richer experiences and stronger personal capacities. Therefore, they ask for higher individual rewards. According to principal-agent theory, when executives have held more shares of their companies, they can get more compensatory income in addition to their salaries such as dividend income etc. In the case that other conditions are the same, for executives who get the same annual salary but hold shares of different proportions, those with lower shareholding ratios will ask to resign a salary-performance contract with shareholders so as to earn higher incomes as compensation. On the other hand, when a company's equity is highly decentralized, the shareholders' supervision over their senior managers will be weakened, for the supervision costs will be relatively high and even more than individual's stock returns, and the individual shareholders do not have enough impetus to supervise and limit the behaviors of the executives. In this situation, shareholders will usually provide executives high pay to motivate them to work with enthusiasm and thus maximize shareholders' interests. While the equity concentration degree is high, big shareholders will have stronger drives to supervise the executives, for their own interests is closely related to corporate performance, which will diminish agency costs to some degree.

\subsection{Variable Selection}

The variables of the research mainly include executive pay variable, executive shareholding ratio variable, corporate performance variable, equity concentration degree variable and some other control variables. Among them, the control variables include firm size variable, company lever level variable and growth capacity variable.

(1) Executive pay (NWP). The executive pay variable is defined as arithmetic average of the total amount of top three executive compensations. To inspect the top three executives' compensations as a whole, it can reflect the pay level of the top management team to the greatest extent and is more representative. The compensation data are from the annual relevant reports disclosed by listed companies, which include executive salary, bonuses, allowances and other incomes.

(2) Executive shareholding ratio (MSR). The ratio is defined as the proportion of total shareholdings of senior management personnel, directors and supervisors in the total share capital of the company. The shares held by executives originally are not further distinguished from those granted by the company, for equity incentive in itself is aimed at making interests of executives and shareholders keep consistent in maximum so as to reduce agency costs. Moreover, the original shares held by the executives are also part of the residual claims of the company and have the same incentive effect in theory. From the disclosed annual reports, we can see that the executive shareholding ratios of China's listed companies are still low at present. There exists a serious phenomenon that many executives have "zero shareholding", and a lot of enterprises are still in a state of looking on. Consequently, equity incentive plays only a limited role in corporate governance in China.

(3) Corporate performance (ROE). Corporate performance refers to operation result of the company, which reflects the resource allocation efficiency and operating result and is usually embodied by one or a group of financial data. There are mainly three indicators in common use to measure the enterprise performance, namely return on equity (ROE), Tobin $\mathrm{Q}$ ratio and return on main business assets (CROA). Here, return of equity (ROE) is chosen as a variable to measure company-operating performance. It is a general index that reflects the capital revenue ability and also the most representative indicator in financial analysis. The index has a strong availability but with the possibility of data distortion.

(4) Equity concentration degree (COCEN). Equity concentration degree is usually measured by three methods, namely $\mathrm{Cr}$ index (refers to the sum of the shareholding ratios of top $\mathrm{n}$ shareholders of the company), Herfindahl index (refers to the sum of squares of the shareholding ratios of top $n$ shareholders of the company) and. $\mathrm{Z}$ index (refers to the ratio of the shareholding ratio of the largest shareholder and that of the second largest shareholder). The data of this variable are obtained from WIND database, and its definition keeps consistent with the same as that in WIND. Here, the sum of the shareholding ratios of top ten shareholders is used to measure equity concentration degree.

(5) Other control variables. Firm size (SCALE) has a few measuring variables. The representative ones are market value of the listed company and total amount of book assets. Market value contains more speculative elements and its 
numerical value is easy to change. While the total accounting assets of a company is comparatively stable and takes on good accuracy as a control variable. Here, the natural logarithm of the total assets (LnSIZE) is selected as the index to measure firm size.

Earnings per share (EPS) refer to the ratio of current net profits and the total share capital of common stock, which is an important index to determine the investment value of a stock.

Asset-liability ratio (LEV) is an important index to measure the proportional relationship between liabilities and assets of a company, which can measure the protection degree for the benefit of creditors when the enterprise is in liquidation and reflect its debt paying ability to some extent.

Net profit growth rate (GROW) is an important index to measure the growth rate of the annual after-tax net profit of a company, which has a good representative in reflecting its growth ability.

\subsection{Model Building}

At present, Domestic and foreign theorists have not yet reached a unanimous conclusion in their research on relationship between executive compensation incentives and corporate performance, especially in correlations between executive pay and executive shareholding ratio and equity concentration degree. There also exist large differences in the empirical results. Therefore, it is particularly critical how to bring all sorts of factors into the model reasonably that influence the level of executive compensation and corporate performance. According to the above assumptions and on the basis of taking into account various factors, model 1 and model 2 are developed to measure corporate performance and executive pay of the company respectively as follows.

$$
\mathrm{ROE}=\mathrm{a} 0+\mathrm{a} 1 \mathrm{NWP}+\mathrm{a} 2 \mathrm{MSR}+\mathrm{a} 3 \mathrm{GROW}+\mathrm{a} 4 \mathrm{LEV}+\mathrm{a} 5 \mathrm{SCALE}+\mathrm{u}
$$

Where the interpreted variable is:

ROE (corporate performance) is rate of return on common stockholders' equity.

The interpreting variables: are:

NWP (executive pay) is the logarithm of arithmetic average of the top three executive pays in annual reports of the company;

MSR (executive shareholding ratio) is the average of the executive shareholding ratios disclosed in annual reports of the company.

The control variables are:

GROW (growth ability) is measured by net profit growth rate of the company;

LEV (financial leverage) is measured by asset-liability ratio of the company;

SCALE (firm size) is measured by the logarithm of total assets of the company.

$$
\mathrm{LnNWP}=\mathrm{b} 0+\mathrm{b} 1 \mathrm{MSR}+\mathrm{b} 2 \mathrm{SCALE}+\mathrm{b} 3 \mathrm{COCEN}+\mathrm{b} 4 \mathrm{EPS}+\mathrm{u}
$$

(model 2)

Where, the interpreted variable is:

LnNWP is the logarithm of the arithmetic average of the top three executive pays.

The interpreting variables are:

MSR is the average executive shareholding ratio;

SCALE is firm size;

COCEN is equity concentration degree of the company;

EPS is earnings per share

\subsection{Sample Selection}

I select the component stocks of Shanghai 180 and Shenzhen 100 indices as research samples, and extract related data of 280 listed companies each year during 2007-2009 to make analysis and regression. In order to guarantee the quality and validity of the data and eliminate the impact of very few abnormal samples on research conclusion, the following samples are eliminated:

(1) Considering the particularity of listed companies in the financial industry in aspects of capital structure, operation and management, hence, companies of this kind are eliminated out of the samples.

(2) Considering the important influence of data integrity on the research, sample companies with incomplete data during 
the three years are eliminated.

(3) Considering the particularity of the sample data of ST-type and PT-type listed companies, the sampling listed companies of this kind are eliminated in order to exclude their interferences in this study.

Finally, 26 financial enterprises and one with incomplete data are excluded, and there are 253 effective samples each year and 759 samples in total in the three years. The data are obtained from the Wind financial database terminal and taken tests by SPSS17.0 and Eviews6.0 after being sorted out.

\section{Analysis of the Empirical Test Results}

The test results of correlations between the independent variables and dependent variables are acquired through descriptive statistical analysis, correlation analysis, and multiple regression analysis and panel data inspection on all sample data during 2007-2009.

\subsection{Descriptive Statistical Analysis}

A descriptive statistical analysis is made on main variables of all samples, and the results are shown in table 1. From the table, it can be seen that the ROE level of China's listed companies is not so high with the average level of corporate performance at $15.42 \%$, and that the average yearly executive pay is about 40,000 RMB Yuan, and that the general level of executive shareholding ratio is not high at only $0.75 \%$.

\subsection{Correlation Inspection}

Coefficients of correlations between each variable are shown in table 2. The results show that corporate performance has a significant positive correlation with annual executive pay and is high positively correlated with executive shareholding ratio, which is consistent with the above theoretical assumptions. Executive pay is also in markedly positive correlation with corporate assets scale, which also maintains consistency with the former theoretical assumption. However, executive pay takes on positive correlations with executive shareholding ratio and equity concentration degree, which is not consistent with the above theoretical assumptions. The reasons might be the particularity of corporate governance structure of the Chinese enterprises and the status quo of executive compensation and organizational structure of China. There remains difference between corporate governance level of China and that of some developed countries, therefore, the actual situations may exist inconsistency with the assumptions.

Among the correlation coefficients between all variables involved in the above models, the largest absolute value of the coefficients is the coefficient between SCALE and LEV with the numerical value at 0.378 close to 0.3 . Therefore, there are weak correlations between variables in the above models. So it can be considered that there does not basically exist the problem of multicollinearity between the two models, and that all variables can be put into one model for regression analysis.

\subsection{Multiple Regression Analysis}

In order to test the correlations between all of the variables better, a panel data inspection is made on model 1 and model 2 through Eviews6.0. The test results are shown in table 3 and table 4.

From the inspection results of model 1 in table 3 , it can be seen that corporate operating performance is of significant positive correlation with the annual executive pay and executive shareholding ratio respectively, and that the significance levels of the coefficients are significant at $1 \%$ confidence level. The results show that corporate performance is of positive correlation with annual executive pay, and that corporate performance is better when executive shareholding ratio is higher, which is consistent with the above theoretical assumptions. When executives hold stocks of the company, their identities will change; they are both operators and owners of it and thus have claims for its residual assets. Hence, the executives will keep their interests in consistency with those of the shareholders, and devote to value maximization of the company and even that of the shareholders, which is just the aim of equity incentive plan of the company.

From the test results of model 2 in table 4, it can be seen that executive pay is high positively related with corporate assets scale with a coefficient significant level within $1 \%$, which is consistent with the former theoretical assumptions. However, the result on correlations between executive pay and executive shareholding ratio and equity concentration degree is not consistent with the above assumptions. The results indicate that executive compensation is in a positive relationship with both executive shareholding ratio and equity concentration degree, but not in negative relationship as described by theories. The reasons may be that the shareholding ratio of senior executives of China's listed companies is relatively low, and executives' shareholding is only a welfare arrangement and cannot play its due roles of incentives, and thus has not achieved the expected incentive effects. At the same time, the equity concentration degree of listed companies is not high yet, and several biggest shareholders do not have enough impetus to monitor the executives, for 
their own interests are not in high correlation with corporate performance, which will influence agency cost to a certain extent.

\section{References}

Bai Xue. (2009). Research on Relations Between Corporate Governance Structure, Executive Compensation and Corporate Performance of China's Listed Companies. Graduate Paper, Beijing Jiaotong University

Coughlan A., \& R. Schmidt. (1985). Managerial Compensation, Management Turnover, and Firm Performance: An Empirical Investigation. Journal of Accounting and Economics, 7, 43-66. http://dx.doi.org/10.1016/0165-4101(85)90027-8

Daniel Bergstresser, \& Thomas Philippon. (2003). CEO Incentives and Earnings Management: Evidence From the 1990s, Working paper, 2003.

Hu Ming. (2003). Empirical Analysis on Top Management Team and Corporate Performance of Listed Companies. Finance \& Trade Economics, 4, 59-62

Jensen, Michael C., \& William H. Meckling. (1976). Theory of the Firm: Managerial Behavior, Agency Costs and Ownership Structure. Journal of Financial Economies, 305-360. http://dx.doi.org/10.1016/0304-405X(76)90026-X

Li Zengquan. (2000). Incentives Mechanism and Corporate Performance: an Empirical Analysis based on Listed Companies. Accounting Research, 1, 24-30

Lin Xiaowan. (2001). Comparison Study on Operators' Pay Incentive Status of Three Years of China's Listed Companies. Modernization of Management, 5, 14-17.

Liu Guoliang, \& Wang Jiasheng. (2000). Positive Analysis of Listed Companies' Equity Structures, Incentive Systems and Performances. Economic Theory and Business Management, 5, 40-45.

LU Jianxin. (2009). Ownership Structure,Corporate Governance and the Eff iciency of Internal Capital Market. Joumal of Zhongnan University of Economics and Law, 4, 120-125.

Lucian Bebchuk, \& Yaniv Grinstein. (2005). Executinve Pay and Firm Size. Working paper, Apr. 2005.

Murphy K J. (1985). Corporate Performance and Managerial Remuneration: An Empirical Analysis. Journal of Accounting and Economies, 7, 11-41. http://dx.doi.org/10.1016/0165-4101(85)90026-6

Sun Yongxiang, \& Huang Zuhui. (1999). Equity Structure and Corporate Performance of China's Listed Companies. Economic Research Journal, 12, 23-30.

Wei Gang. (2000). Incentives for Top-Management and Performance of Listed Companies. Economic Research Journal, 3, 32-40.

XU Yixuan. (2010). Pay Dispersion, Performance and Corporate Governance: Empirical Evidences from Chinese Listed Companies. Journal of Shanxi Finance and Economics University, 7, 86-93.

Yan Lirong L., \& iu Fang. (2006). An Empirical Study on the Correlation Between Operators' Incentive Compensation and Firm's Performance in Listed Firms. Statistics \& Information Forum, 1, 101-104.

Zhang Jinlin, \& Zhao Qing. (2010). Empirical Study on Relations Between Top Management Compensation and Corporate Performance of China's Listed Companies. Inquiry Into Economic Issues, 6, 81-87.

Table 1. Result on all variables of descriptive statistical analysis during 2007-2009

\begin{tabular}{|c|c|c|c|c|c|}
\hline Variable & $\mathrm{N}$ & Minimum & Maximum & Average & Std. deviation \\
\hline ROE & 759 & -0.55 & 1.03 & 0.154 & 0.142 \\
\hline NWP & 754 & 1.37 & 6.23 & 3.865 & 0.758 \\
\hline MSR & 759 & 0.00 & 0.37 & 0.008 & 0.040 \\
\hline GROW & 759 & -528.24 & 142.56 & 0.123 & 20.165 \\
\hline LEV & 759 & 0.05 & 0.97 & 0.507 & 0.175 \\
\hline SCALE & 759 & 11.00 & 18.79 & 13.980 & 1.229 \\
\hline COCEN & 759 & 0.01 & 0.96 & 0.240 & 0.191 \\
\hline EPS & 759 & -0.02 & 0.06 & 0.006 & 0.007 \\
\hline Effective N (in listing state) & 754 & & & & \\
\hline
\end{tabular}


Table 2. Result of Pearson correlation inspection on all variables during 2007-2009

\begin{tabular}{|c|l|l|l|l|l|l|l|l|}
\hline Variable & ROE & NWP & MSR & GROW & LEV & SCALE & COCEN & EPS \\
\hline ROE & 1 & & & & & & & \\
\hline NWP & $0.147 * *$ & 1 & & & & & & \\
\hline MSR & $0.145^{* *}$ & $0.091 *$ & 1 & & & & & \\
\hline GROW & $0.107 * *$ & -0.047 & 0.005 & 1 & & & & \\
\hline LEV & $-0.112^{* *}$ & $0.130 * *$ & -0.044 & -0.011 & 1 & & & \\
\hline SCALE & -0.047 & $0.311^{* *}$ & $-0.109 * *$ & $-0.089 *$ & $0.378^{* *}$ & 1 & & \\
\hline COCEN & -0.021 & $0.179 * *$ & 0.034 & -0.024 & 0.003 & $0.194 * *$ & 1 & \\
\hline EPS & $0.720 * *$ & $0.191 * *$ & 0.069 & $0.071 *$ & $-0.126 * *$ & 0.028 & 0.058 & 1 \\
\hline
\end{tabular}

Note: $* *, *$ denote significant correlation at $1 \%$ and $5 \%$ confidence levels (bilateral) respectively

Table 3. Result of multiple regression analysis of model 1 during 2007-2009

\begin{tabular}{|c|c|c|c|c|}
\hline \multicolumn{5}{|l|}{ Dependent Variable: ROE } \\
\hline Method: Panel Least Squares \\
\hline Variable & Coefficient & Std. Error & t-Statistic & Prob. \\
\hline C & 0.147 & 0.059 & 2.491 & 0.013 \\
\hline NWP & 0.032 & 0.007 & 4.546 & 0.000 \\
\hline MSR & 0.429 & 0.127 & 3.383 & 0.001 \\
\hline GROW & 0.001 & 0.001 & 3.117 & 0.002 \\
\hline LEV & -0.099 & 0.031 & -3.232 & 0.0001 \\
\hline SCALE & -0.005 & 0.005 & -1.056 & 0.291 \\
\hline R-squared & 0.272 & Prob. (F-statistic) & 0.000 \\
\hline Adjusted R-squared & 0.266 & Durbin- Watson stat & 1.536 \\
\hline
\end{tabular}

Table 4. Result of multiple regression analysis of model 2 during 2007-2009

\begin{tabular}{|c|c|c|c|c|}
\hline \multicolumn{5}{|l|}{ Dependent Variable: NWP } \\
\hline Method: Panel Least Squares \\
\hline Variable & Coefficient & Std. Error & t-Statistic & Prob. \\
\hline C & 1.065 & 0.295 & 3.605 & 0.000 \\
\hline MSR & 1.925 & 0.648 & 2.971 & 0.003 \\
\hline SCALE & 0.183 & 0.021 & 8.588 & 0.000 \\
\hline EPS & 13.377 & 3.243 & 4.124 & 0.000 \\
\hline COCEN & 0.736 & 0.176 & 4.192 & 0.000 \\
\hline R-squared & 0.153 & Prob. (F-statistic) & 0.000 \\
\hline Adjusted R-squared & 0.149 & Durbin-Watson stat & 1.379 \\
\hline
\end{tabular}

